\title{
RANCANG BANGUN MOBILE LEARNING BERBASIS ANDROID UNTUK MEMUDAHKAN PROSES BELAJAR MENGAJAR JARAK JAUH DI SMKN SUKARESIK
}

\author{
Ms Chandra Tri Saputra ${ }^{1)}$, Taofik Muhammad ${ }^{2)}$, Muhammad Taufiq ${ }^{3)}$, \\ 1,2,3) Pendidikan Teknologi Informasi FKIP Universitas Muhammadiyah Tasikmalaya \\ email : $\underline{\text { mschandratrisaputra@gmail.com }}{ }^{1)}, \underline{\text { taofik.muhammad@umtas.ac.id }{ }^{2}}, \underline{\text { mtaufig@umtas.ac.id }{ }^{3)}}$
}

\begin{abstract}
Abstraksi
Mobile learning dapat digunakan sebagai alternatif dalam melaksanakan kegiatan belajar mengajar sebagai pelengkap atas kegiatan pembelajaran yang sudah ada. Khusus di satuan Pendidikan SMKN SUKARESIK, belum tersedia fasilitas mobile learning berbasis android di SMKN SUKARESIK yang dapat menyediakan media pembelajaran untuk mengakomodasi pendidik yang berguna dalam menyampaikan pembelajaran di luar kelas serta dapat diakses oleh peserta didik kapanpun dan dimanapun dengan mudah. Penelitian ini bertujuan untuk mengetahui bagaimana merancang tools pemodelan sistem yang ada dalam aplikasi mobile learning di SMKN SUKARESIK berbasis android menggunakan perangkat lunak Android Studio dan menghasilkan aplikasi mobile learning berbasis android yang dapat memudahkan proses belajar mengajar jarak jauh baik bagi pendidik maupun peserta didik di SMKN SUKARESIK. Jenis Penelitian ini menggunakan desain $R \& D$ dan model pengembangan yang digunakan adalah ADDIE yaitu Analisis (Analysis), Desain (Design), Pengembangan (Development), Implementasi (Implementation), Evaluasi (Evaluation). Populasi penelitian adalah kelas XI TKJ dengan sampel 30 peserta didik. Hasil penelitian diperoleh nilai kelayakan dari segi Rekayasa Perangkat Lunak dan Komunikasi Visual seesar 77,24\% dalam kategori Baik, nilai kelayakan dari praktisi pembelajaran diperoleh sebesar 84,63\% yan berada dalam kategori Sangat Baik, sedangkan nilai kelayakan dari perspektif peserta didik diperoleh sebesar 74,84 yang berada dalam kategori Baik.
\end{abstract}

Kata Kunci: Mobile Learning, Proses Pembelajaran, Android

\begin{abstract}
Mobile learning can be used as an alternative in carrying out teaching and learning activities as a complement to existing learning activities. Especially in the SMKN SUKARESIK education unit, there is no android-based mobile learning facility at SMKN SUKARESIK which can provide learning media to accommodate educators who are useful in delivering learning outside the classroom and can be accessed by students anytime and anywhere easily. This study aims to determine how to design system modeling tools in the Android-based mobile learning application at SMKN SUKARESIK using Android Studio software and produce an Android-based mobile learning application that can facilitate the distance teaching and learning process for both educators and students at SMKN SUKARESIK. . This type of research uses $R \& D$ design and the development model used is ADDIE, namely Analysis, Design, Development, Implementation, Evaluation. The study population was class XI TKJ with a sample of 30 students. The results showed that the feasibility value in terms of Software Engineering and Visual Communication was $77.24 \%$ in the Good category, the feasibility value of learning practitioners was $84.63 \%$ which was in the Very Good category, while the feasibility value from the perspective of students was 74. , 84 which is in the Good category.
\end{abstract}

Keywords: Mobile Learning, Learning Process, Android

\section{PENDAHULUAN}

Perkembangan teknologi saat ini banyak memberi pengaruh terhadap cara hidup kita. Salah satunya adalah dalam bidang pendidikan dengan penggunaan mobile learning. Dewasa kini mobile learning sudah mulai di implementasikan pada kegiatan pembelajaran di instansi pendidikan, perguruan tinggi, tempat-tempat kursus, bahkan komunitas-komunitas sudah mulai menggunakan konsep seperti ini. Mobile learning dapat digunakan sebagai alternatif dalam melaksanakan kegiatan belajar mengajar sebagai pelengkap atas kegiatan pembelajaran yang sudah ada. Permasalahan yang dihadapi instansi pendidikan dipengaruhi oleh beberapa faktor salah satunya 
faktor sumber pelajaran, sumber belajar sesungguhnya banyak sekali. Pemanfaatan sumber-sumber belajar tersebut tergantung pada kreativitas pendidik, waktu, biaya serta kebijakan-kebijakan lainnya. Interaksi edukatif tidaklah berproses dalam kehampaan, tetapi ia berproses dalam kemaknaan.

Khusus di satuan Pendidikan SMKN SUKARESIK, belum tersedia fasilitas mobile learning berbasis android di SMKN SUKARESIK yang dapat menyediakan media pembelajaran untuk mengakomodasi pendidik yang berguna dalam menyampaikan pembelajaran di luar kelas serta dapat diakses oleh peserta didik kapanpun dan dimanapun dengan mudah. Dengan adanya peluang ini, muncul sebuah ide untuk mengembangkan mobile learning berbasis android yang dapat menghasilkan sebuah hal menjadi lebih efisien dalam bidang pendidikan, yaitu dengan berinovasi pada media pembelajaran berupa mobile learning berbasis android.

Dengan adanya mobile learning ini dapat memudahkan pendidik dan peserta didik dalam memberikan pembelajaran, presensi dan tugas. Karena produk ini berbentuk software berbasis android yang didukung dengan user interface yang user friendly dan dapat digunakan dimana saja, sehingga akan lebih efisien dalam penggunaannya. Hadirnya aplikasi ini disisi lain berguna untuk membantu pendidik dan peserta didik dalam pembelajaran menggunakan mobile learning tipe synchronous yang berarti "tepat pada waktu yang bersamaan". Terdapat beberapa fitur atau layanan yang disediakan dalam aplikasi ini, pertama yaitu fitur yang menyediakan platform chatting antara pendidik dan peserta didik. Didalam platform ini pendidik dan peserta didik dapat saling berinteraksi secara langsung. Dalam fitur atau layanan absensi menggunakan QR-code yang terintegrasi secara langsung kedalam aplikasi android. Selain itu ada satu fitur khusus sebagai pengingat untuk pendidik, yaitu apabila pendidik terlambat masuk kelas dan ada di luar area kelas dengan jarak tertentu, maka pendidik akan mendapatkan notifikasi untuk segera hadir ke kelas. Berdasarkan uraian di atas, akan dilakukan penelitian dengan judul "Rancang Bangun Mobile Learning Berbasis Android untuk Memudahkan Proses Belajar Mengajar Jarak Jauh di SMKN Sukaresik".

Penelitian ini bertujuan untuk mengetahui bagaimana merancang tools pemodelan sistem yang ada dalam aplikasi mobile learning di SMKN SUKARESIK berbasis android menggunakan perangkat lunak android studio dengan menggunakan pemodelan sistem menggunakan UML berupa Usecase, Class Diagram, Activity Diagram, Sequence Diagram, Entity Relationship Diagram (ERD), Logical Record Structure (LRS) dan MySQL. Tujuan lainnya yaitu untuk menghasilkan aplikasi mobile learning berbasis android yang dapat memudahkan proses belajar mengajar jarak jauh bagi pendidik maupun peserta didik di SMKN Sukaresik.

Agar penelitian memperoleh kajian yang tepat maka perlu dibatasi cakupan permasalahnnya yaityu dengan membangun aplikasi mobile learning menggunakan Android Studio, membuat perancangan aplikasi mobile learning menggunakan UML, mengimplementasikan mobile learning dilakukan di SMKN SUKARESIK Kelas XI Teknik Komputer dan Jaringan (TKJ). Kemudian objek yang diteliti bertujuan untuk memudahkan proses belajar mengajar jarak jauh di SMKN SUKARESIK, meliputi pengolahan data User (Administrator, Pendidik, Peserta didik), Absensi Menggunakan QR-code, Melihat Informasi Instansi pendidikan, Melihat Jadwal, Melihat Nilai, Materi Pelajaran dan tugas (Upload dan Download), Notifikasi untuk pendidik apabila berada diluar area kelas.

Penelitian yang relevan diambil dari penelitian milik Maranthika Setyantoko (2016) [5] yang berjudul "Pengembangan Media Pembelajaran Mobile Learning Berbasis Android Dalam Pembelajaran Atletik Untuk Peserta Didik SMP Kelas VII”. Penelitian ini menghasilkan Aplikasi Pengembangan Media Pembelajaran Mobile Learning Berbasis Android dalam Pembelajaran Atletik untuk Peserta didik SMP Kelas VII. Dengan demikian media pembelajaran Atletik dengan aplikasi Athletic Smart Apps berbasis Android ini layak digunakan sebagai media pembelajaran PJOK cabang olahraga atletik khususnya peserta didik SMP kelas VII. Perbedaanya terletak pada kegunaannya, pada penelitian terdahulu mobile learning digunakan untuk media pembelajaran PJOK cabang olahraga atletik khususnya peserta didik SMP kelas VII. Sedangkan pada penelitian ini mobile learning digunakan untuk sumber belajar dan memudahkan kegiatan proses belajar mengajar jarak jauh. Persamaan penelitian terdahulu dengan penelitian ini terletak pada mobile learning sebagai media pembelajaran online dan android sebagai platform.

Penelitian ini tidak terlepas dari tinjauan pustaka yang telah dilakukan pada tahap kajian teori yang berguna dalam rangka mendukung proses penelitian untuk memberi penguatan dari segi teori yang membersamai keberlangsungan penelitian. Tinjauan pustaka dalam penelitian ini yaitu sebagai berikut:

\section{Rancang Bangun}

Rancang bangun adalah prosedur dalam membangun sebuah sistem yang diterjemahkan dari sebuah hasil analisa kebutuhan ke dalam bahasa pemrograman tertentu. Menurut Zulfiandri (2014:474) Rancang bangun adalah kegiatan menerjemahkan hasil analisa ke dalam bentuk paket perangkat lunak kemudian menciptakan sistem tersebut ataupun memperbaiki sistem yang sudah ada [12]. 


\section{Mobile Learning}

Menurut Arif (2016: 116) mobile learning merupakan interseksi dari mobile computing dan e-learning yang menyediakan sumber daya yang dapat diakses dari manapun, kemampuan sistem pencarian yang tangguh, interaksi yang kaya, dukungan yang penuh terhadap pembelajaran yang efektif dan penilaian berdasarkan kinerja. Dalam pengertian tersebut menyinggung pada mobile computing merupakan perangkat yang terkoneksi ke internet tanpa jaringan kabel yang saling terhubung [1]. Pada intinya mobile computing merupakan sebuah perangkat portable yang dapat digunakan tanpa jaringan kabel (nirkabel).

Sistem m-learning ini menurut Sarrab et al. [7] memanfaatkan mobilitas dari perangkat handheld / mobile, seperti handphone dan Personal Digital Assistant (PDA), untuk memberikan suatu fungsi pembelajaran yang dapat dilakukan di mana pun dan kapan pun. Mobile learning tidak dapat menggantikan kelas tradisional tetapi dapat digunakan sebagai pelengkap dalam proses pembelajaran di kelas dan universitas [2].

Hartanto mengemukakan pendapatnya bahwa manfaat e-learning bagi dunia pendidikan diantaranya adalah fleksibel dalam memilih waktu dan tempat untuk mengakses pelajaran, independent learning yaitu E-learning memberikan kesempatan bagi pembelajar untuk memegang kendali atas kesuksesan belajar masing-masing, hemat biaya (transportasi akomodasi, administrasi pengelolaan, penyediaan sarana dan fasilitas), fleksibel dalam kecepatan pembelajaran yaitu E-learning dapat disesuaikan dengan kecepatan belajar masing-masing peserta didik, memiliki standardisasi pengajaan berupa persamaan kualitas setiap mengakses elearning dan tidak tergantung kondisi pendidik, efektifitas pengajaran, kecepatan distribusi karena E-learning dapat dengan cepat menjangkau ke seluruh penjuru, on demand artinya E-learning dapat diakses sewaktu-waktu dan yang terakhir adalah otomatisasi proses administrasi [3].

\section{Android}

Android adalah sistem operasi berbasis Linux yang dirancang untuk perangkat bergerak layar sentuh seperti telepon pintar dan komputer tablet. Android awalnya dikembangkan oleh Android, Inc., dengan dukungan finansial dari Google, yang kemudian membelinya pada tahun 2005. Sistem operasi ini dirilis secara resmi pada tahun 2007, bersamaan dengan didirikannya Open Handset Alliance, konsorsium dari perusahaan-perusahaan perangkat keras, perangkat lunak, dan telekomunikasi yang bertujuan untuk memajukan standar terbuka perangkat seluler. Ponsel Android pertama mulai dijual pada bulan Oktober 2008 [4].

Komponen utama android terdiri dari beberapa elemen pendukung dengan susunan dari komponen utama android menurut Yudhanto Yudha \& Wijayanto Ardhi (2017: 3) yaitu terdiri dari Aplikasi, Java API Framework, library and android runtime, hardware abstraction layer (HAL), kernel Linux [11]. Aplikasi berada setingkat dengan aplikasi sistem inti untuk email, perpesanan SMS, kalender, penjelajahan internet, atau kontak. Pada Java API Framework, semua fitur android tersedia untuk developer melalui antarmuka pemrograman aplikasi. Bagian library and android runtime terdiri dari aplikasi yang berjalan pada prosesnya sendiri dan dengan Intance Android Runtime sendiri, yang memungkinkan beberapa mesin sekaligus virtual pada perangkat bermemori rendah, android juga menyediakan rangkaian library waktu proses inti yang menyediakan sebagian besar fungsionalitas bahasa pemrograman Java. Hardware abstraction layer menyediakan antarmuka standar yang menunjukan kemampuan perangkat kerjas ke kerangka kerja Java API (Application Programming Interface) yang lebih tinggi. Terakhir adalah kernel linux yang merupakan Fondasi platform android.

\section{Pembelajaran}

Belajar adalah perubahan tingkah laku pola pikir seseorang baik disengaja ataupun tidak disengaja, kemudian dengan belajar akan terjadinya proses menuju perubahan pola pikir dari seseorang tersebut. Sedangkan Aunurrahman (2013) mengemukakan belajar menunjukkan aktivitas yang dilakukan oleh seseorang yang disadari atau disengaja. Aktivitas ini menunjuk pada keaktifan seseorang dalam melakukan aspek mental yang memungkinkan terjadinya perubahan pada dirinya [4]. Mengajar merupakan suatu usaha untuk menciptakan kognisi dalam bentuk perolehan ilmu pengetahuan dilengkapi dengan kondisi lingkungan yang sangat mendukung dan memungkinkan untuk berlangsungnya proses belajar. Herman (1998: 5) memberikan pengertian bahwa mengajar adalah suatu kegiatan dimana pengajar menyampaikan pengetahuan atau pengalaman yang dimiliki kepada peserta didik [9].

Djamarah (Pane., \& Dasopang, 2017: 337) menjelaskan bahwa pembelajaran hakikatnya merupakan proses untuk mengatur dan mengorganisasi lingkungan disekitar peserta didik sehingga dapat menumbuhkan serta mendorong peserta didik dalam melakukan proses belajar [6]. Pembelajaran berperan sebagai proses memberikan bimbingan atau bantuan kepada peserta didik dalam melakukan proses belajar. Pendidik berperan sebagai pembimbing. Dalam belajar tentunya banyak perbedaan, adanya peserta didik yang mampu mencerna materi pelajaran, dan ada pula peserta didik yang terlambat dalam mencerna materi pelajaran. Kedua perbedaan inilah yang mengharuskan pendidik memiliki kemampuan untuk mengatur strategi dalam pembelajaran yang sesuai 
dengan keadaan setiap peserta didik. Oleh karena itu, hakikat belajar adalah "perubahan", sementara hakikat pembelajaran adalah "pengaturan".

Sedangkan menurut Sunhaji (2014: 32) mengemukakan bahwa proses pembelajaran adalah suatu usaha untuk membuat peserta didik belajar, sehingga situasi ini disebut sebagai peristiwa belajar (event of learning) [10]. Peristiwa ini menjadi suatu bentuk usaha untuk terjadinya perubahan tingkah laku dari peserta didik. Proses pembelajaran ditandai dengan adanya keberlangsungan interaksi edukatif yang terjadi selama pembelajaran, yaitu interaksi yang sadar akan tujuan.

\section{Distance Learning}

Model pembelajaran jarak jauh adalah bagian dari lingkup E-learning berupa media on-line yang memiliki sumber untuk menunjang proses kegiatan belajar mengajar berbasis teknologi informasi melalui internet.

\section{METODE PENELITIAN}

Bagian Metode penelitian yang digunakan dalam penelitian ini mengacu pada Model R\&D dengan prosedur penelitian ini mengadaptasi model pengembangan ADDIE yaitu analysis, design, development, implementation dan evaluation. Pemilihan model ini didasari atas pertimbangan bahwa model ini dikembangkan secara sistematis dan berlandaskan teoretis desain pembelajaran. Subjek ujicoba dilakukan ke peserta didik kelas XI jurusan Teknik Komputer dan Jaringan (TKJ) di SMKN SUKARESIK. Langkah-langkah dalam melakukan penelitian diawali dengan tahapan penelitian yang sesuai dengan rumusan dan tujuan penelitian yaitu Analisis, perancangan pengembangan, implementasi, evaluasi dan pembuatan laporan. Teknik pengumplan data menggunakan angket dan dokumentasi. Angket ditujukan kepada validator ahli rekayasa perangkat lunak dan komunikasi visual, validator ahli praktisi pembelajaran serta angket respon pendidik dan peserta didik.

\section{Peralatan Pendukung Program (Tools System)}

Tool System yang digunakan dalam penelitian ini sebagai berikut:

a. UML (Unified Modeling Language)

b. Usecase

c. Class Diagram

d. Activity Diagram

e. Sequence Diagram

f. Entity Relation Diagram (ERD)

g. Logical Record Structure (LRS)

h. Bahasa Pemrograman Java

i. Bahasa pemrograman PHP

j. $\quad$ MY Structure Query Language (MySQL)

k. Android Studio

1. ADDIE (Analyze, Design, Develop, Implement, dan Evaluate)

Teknik analsis data dalam penelitian ini menggunakan pendekatan desktriptif kualitatif dimana peneliti akan mengolah data menjadi kumpulan informasi. Analisis data secara pendekatan desktiprif kualitatif dilakukan dengan menganalisis data hasil ahli media, ahli pembelajaran dan peserta didik sebagai pengguna produk. Penilaian angket menggunakan formula presentase nilai yaitu sebagai berikut:

$$
P=\frac{F}{N} x 100
$$

Keterangan:

$\mathrm{P}=$ Presentase

$\mathrm{F}=$ Skor yang diperoleh

$\mathrm{N}=$ Skor Maksimal

Angket hasil respon peserta didik terhadap produk yang dibuat kemudian dihitung kembali untu kmelihat persebaran frekuensi jawaban yang berguna untuk mengetahui persebaran nilai yang diberikan oleh peserta didik dengan menggunakan rumus kaidah Sturges (Panaha; Manginsela; dan Salaki, 2018: 64), yaitu sebagai berikut:

- Menentukan Nilai Range

$$
\text { Range = Nilai Maksimal - Nilai Minimal }
$$


- Menentukan Banyak Kelas

Keterangan:

$$
K=1+3,3 \log N
$$

$\mathrm{K}$ = Banyaknya Kelas

$\mathrm{N}=$ Jumlah Responden

- Menentukan Nilai Interval

Keterangan:

$$
I=\frac{\text { Range }}{\text { Banyaknya Kelas }}
$$

I = Interval

$\mathrm{R}=$ Rentang

Hasil pengolahan data dari ketiga instrumen kemudian dianalisis untuk mendapatkan penilaian terhadap produk dari keseluruhan aspek penilaian.

Keterangan:

$$
\frac{\text { Rentang }}{\text { Banyak Kelas Interval }}
$$

$\mathrm{P}=$ Panjang Kelas Interval

Rentang = Nilai Maksimum - Nilai Minimum

Banyak Kelas Interval $=5$

Berdasarkan keterangan tersebut dapat dilakukan perhitungan untuk menentukan interval nilai yaitu sebagai berikut:

$\begin{array}{ll}1 \%-20,8 \% & \text { Sangat Kurang } \\ 20,9 \%-40,6 \% & \text { Kurang } \\ 40,7 \%-60,4 \% & \text { Cuku Baik } \\ 60,5 \%-80,3 \% & \text { Baik } \\ 80,4 \%-100 \% & \text { Sangat Baik }\end{array}$

$$
P=\frac{100-1}{5}=19.8 \%
$$

\section{HASIL DAN PEMBAHASAN}

Media pembelajaran ini adalah mobile learning yang diberi nama sebagai Nambah Ilmu. Filosofi nama nambah ilmu diambil dari maanfaat dari media pembelajaran yang diharapkan akan selalu memberikan ilmu ketika peserta didik menggunakan media pembelajaran ini dalam kesehariannya. Nambah ilmu berupa aplikasi android dengan minimum operating system android 4.1 Jelly Bean, penggunaan nambah ilmu diimplementasikan di SMKN SUKARESIK. Pembuatan media pembelajaran mobile learning yang diberi nama Nambah Ilmu ini harus memenuhi beberapa tahap dalam proses pembuatannya dari mulai analisis kebutuhan sampai tahap evaluasi.

\section{Tahap Analisis}

Permasalahan yang dihadapi instansi pendidikan dipengaruhi oleh beberapa faktor salah satunya faktor sumber pelajaran, sumber belajar sesungguhnya banyak sekali. pemanfaatan sumber-sumber belajar tersebut tergantung pada kreativitas pendidik, waktu, biaya serta kebijakan-kebijakan lainnya. Khusus di satuan Pendidikan SMKN SUKARESIK, sudah menyediakan fasilitas server yang cukup memadai. Namun demikian terdapat peluang untuk dalam pemanfaatan server yang dapat digunakan untuk keperluan sekolah yaitu dalam menyediakan sumber belajar online. Artinya belum tersedia platform khusus yang dikembangan secara mandiri oleh instansi pendidikan ini dalam menyediakan

fasilitas berbasis online khususnya mobile learning berbasis android di SMKN SUKARESIK yang dapat menyediakan media pembelajaran untuk mengakomodasi pendidik dalam menyampaikan pembelajaran di luar kelas serta dapat diakses oleh peserta didik kapanpun dan dimanapun dengan mudah. Adanya peluang ini, memunculkan sebuah ide untuk mengembangkan mobile learning berbasis android yang dapat menghasilkan sebuah hal menjadi lebih efisien dalam bidang pendidikan, yaitu dengan berinovasi pada media pembelajaran berupa mobile learning berbasis android.

Produk ini berbentuk software berbasis android yang didukung dengan user interface yang user friendly dan bisa digunakan dimana saja, sehingga akan lebih efisien dalam penggunaannya. Hadirnya aplikasi ini disisi lain 
berguna untuk membantu pendidik dalam hal pemanfaatan waktu belajar seperti ketika pendidik tidak bisa hadir ke kelas dan peserta didik dalam pembelajaran menggunakan mobile learning tipe synchronous yang berarti "tepat pada waktu yang bersamaan".

\section{Tahap Desain}

Dari metode penelitian diperoleh hasil pengembangan aplikasi mobile learning berbasis Android untuk kompetensi Pemrograman Berorientasi Objek yang meliputi: Diagram UML, ERD, LRS, Story Board serta hasil dari pembuatan aplikasi dengan data berupa tampilan dan tabel hasil pengujian.

\section{a. Usecase Diagram}

Use Case Diagram pada penelitian ini memiliki 3 aktor yaitu peserta didik, pendidik dan wakasek kurikulum sebagai administrator. Peserta didik dan pendidik memiliki hak akses di aplikasi android sedangkan wakasek kurikulum sebagai administrator memiliki hak akses di website admin. Use Case Diagram yang terdapat pada aplikasi media pembelajaran berbasis android pada peserta didik dan pendidik adalah login, logout, terima notifikasi, ubah profile, melihat jadwal, absensi harian menggunakan scan qr-code, generate qr-code, melihat nilai peserta didik, melihat peserta didik, melihat pendidik, melihat berita, melihat pengumuman, melihat slider image, upload materi dan tugas, download materi dan tugas, lihat diskusi materi dan tugas, balas diskusi materi dan tugas.

Sedangkan pada bagian wakasek kurikulim sebagai administrator adalah login, logout, kelola pengguna, kelola kelas, kelola jurusan, kelola wali kelas, kelola tahun ajaran, kelola ruangan, kelola berita, kelola pengumuman, kelola slider image, kelola kompetensi sikap, kelola mata pelajaran, kelola mata pelajaran pendidik, kelola jadwal pelajaran, kelola semester, kelola ekstrakulikuler, kelola kompetensi pengetahuan dan keterampilan, lihat absensi peserta didik, mengelola pengaturan.

\section{b. Activity Diagram}

Activity diagram mengacu pada use case yang telah didefinisikan diatas, activity diagram memberikan alur dari media pembelajaran yang dikembangkan. Pada penelitian ini dibagi menjadi 3 bagian activity diagram, yang pertama pendidik sebanyak 18 activity diagram, yang kedua peserta didik sebanyak 18 activity diagram dan juga wakasek kurikulum sebagai administrator sebanyak 19 activity diagram. Setiap activity diagram memberikan gambaran alur setiap case nya.

\section{c. Class Diagram}

Class diagram digunakan untuk menggambarkan serta deskripsi atau penggambaran dari setiap class. Aplikasi yang dikembangkan terdiri dari 20 class diagram yaitu LoginActivity, MainActivity, NotificationService, FragBeranda, MateriDanTugas, Materi, DetailIsiMateri, JadwalSemester, ListPendidik, ListBerita, ListPengumuman, ListPesertaDidikKelas, ListPesertaDidik, NilaiKelasPesertaDidik, NilaiPesertaDidik, AbsensiJadwal, Absensi, AbsensiHarianPesertaDidik, dan AbsensiHarianPendidik.

\section{d. Sequence Diagram}

Sequence diagram menunjukkan interaksi antar sejumlah objek dan menunjukkan komunikasi rangkaian pesan yang dikirim antara objek juga interaksi antara objek. Sequence diagram berkaitan erat dengan use case diagram dan class diagram.

\section{e. ERD (Entity Relationship Diagram)}

ERD (Entity Relationship Diagram) untuk menganalisis suatu hubungan dari data yang hendap disimpan di dalam basis data sehingga mengurangi kemungkinan terjadinya kekacauan data seperti adanya tabrakan data, oleh karenanya diperlukan sebuah ERD (Entity Relationship Diagram) yang memudahkan peneliti untuk mendapatkan gambaran tentang database yang dibuat.

\section{f. LRS (Logical Record Structure)}

Setelah menggambarkan ERD (Entity Relationship Diagram), selanjutnya ditransformasikan ERD (Entity Relationship Diagram) tersebut ke LRS (Logical Record Structure) untuk Menentukan kardinalitas, jumlah table dan Foreign Key (FK), oleh karenanya diperlukan sebuah LRS (Logical Record Structure) yang memudahkan peneliti untuk mendapatkan gambaran tentang table-table yang dibuat. 


\section{g. Storyboard}

Storyborad berisi sketsa rancangan desain antar muka (user interface) sebelum dilanjut pada tahap pengembangan, storyboard ini dibuat pada aplikasi Adobe XD 7.0.12.
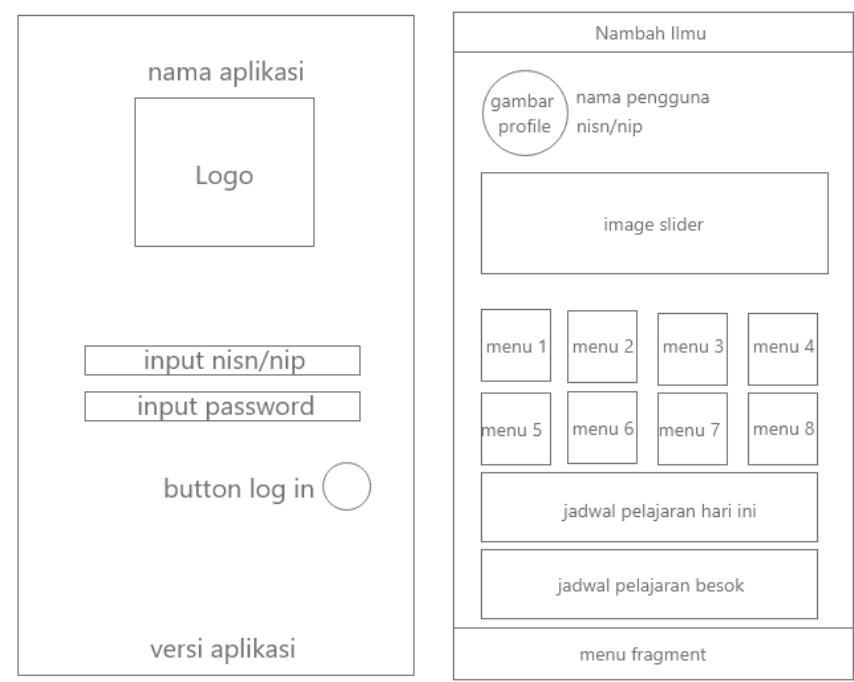

Gambar 1. Login dan Halaman Utama

\section{h. Desain Background, Font, gambar dan Tombol}

Desain backround menggunakan warna biru dengan kode warna \#025ba3 yang disesuaikan dengan logo dari sekolah SMKN SUKARESIK. Font yang digunakan memiliki 3 jenis yaitu Montserrat bold, Montserrat light, Montserrat semibold. Sedangkan pada bagian gambar dan tombol menggunakan icon-icon yang sudah tersedia di software android studio dan mengunduh dari berbagai sumber serta terdapat beberapa yang menggunakan coding $\mathrm{xml}$.

\section{i. Pembuatan Desain Awal Media Pembelajaran Mobile Learning}

Pemilihan nuansa warna menggunakan warna biru dengan kode warna \#025ba3 yang disesuaikan dengan logo dari sekolah SMKN SUKARESIK. Logo aplikasi, domain, hosting dan server ditentukan oleh pihak sekolah SMKN SUKARESIK. Domain yang digunakan untuk mengakses nambah ilmu administrator yaitu http://smknsukaresik.sch.id/nambah_ilmu.

\section{j. Instrumen Kelayakan}

Instrumen kelayakan dinilai dari segi Rekayasa Perangkat Lunak dan Komunikasi Visual, Praktisi Pembelajaran serta dinilai dari segi Peserta Didik. Pada setiap penilaian memiliki beberapa aspek yang berbeda yang dapat disebut sebagai kisi-kisi yang akan diukur untuk menentukan kualitas dan kelayakan mobile learning. Instrumen Kelayakan Rekayasa Perangkat Lunak dan Komunikasi Visual memiliki 3 aspek yang akan diukur yaitu Rekayasa Perangkat Lunak, Analisis PIECES dan Komunikasi Visual. Instrumen Kelayakan Praktisi Pembelajaran memiliki 4 aspek yang akan diukur yaitu Kemudahan Instalasi, Komunikasi Visual, Media Pembelajaran, Manajemen Pemodelan system. Instrumen Kelayakan Peserta Didik memiliki 4 aspek yang akan diukur yaitu Kemudahan Instalasi, Komunikasi Visual, Media Pembelajaran, Manajemen Pemodelan sistem.

\section{Tahap Pengembangan}

Pada tahap ini produk media pembelajaran mobile learning berbasis android dibuat sesuai dengan format pemodelan pada tahap desain. Kemudian dilakukan validasi produk oleh validator ahli yaitu ahli rekayasa perangkat lunak dan komunikasi visual, ahli praktisi pembelajaran dan ahli angket peserta didik. Hasil penilaian akhir akan dikonversikan kedalam beberapa kategori sebagai berikut: 
Tabel 1. Kategori Skor

\begin{tabular}{|c|c|}
\hline Rentang Nilai & Keterangan \\
\hline $1 \%-20,8 \%$ & Sangat Kurang \\
\hline $20,9 \%-40,6 \%$ & Kurang \\
\hline $40,7 \%-60,4 \%$ & Cukup Baik \\
\hline $60,5 \%-80,3 \%$ & Baik \\
\hline $80,4 \%-100 \%$ & Sangat Baik \\
\hline
\end{tabular}

\section{a. Validasi Ahli Rekayasa Perangkat Lunak dan Komunikasi Visual}

Angket ini berisi 29 pernyataan yang harus dinilai oleh ahli dari aspek rekayasa perangkat lunak, analisis PIECES dan komunikasi visual. Masing-masing item memiliki skor maksimal 5 dan skor minimal 1. Skor maksimal keseluruhan angket yaitu 5x29 diperoleh skor maksimal angket sebesar 145. Perolehan skor aktual sebesar 112, sehingga penilaian akhir diperoleh skor $77,24 \%$ yang berasal dari hasil pembagian skor aktual dengan skor maksimal angket lalu dikali $100 \%$ untuk menentukan presentase skor akhir dan berada pada kategori Baik. Berikut adalah rincian dari perolehan skor:

Tabel 2. Rincian Perolehan Skor Ahli

Rekayasa Perangkat Lunak dan Komunikasi Visual

\begin{tabular}{|c|c|c|c|c|c|}
\hline \multicolumn{3}{|c|}{ Aspek } & Total & Skor Akhir & Kategori \\
\hline 1 & 2 & 3 & \multirow{2}{*}{112} & $77,24 \%$ & Baik \\
\hline 41 & 47 & 24 & & & \\
\hline
\end{tabular}

\section{b. Validasi Ahli Praktisi Pembelajaran}

Angket ini berisi 36 pernyataan yang harus dinilai oleh ahli dari praktisi pembelajaran yang berjumlah 3 orang masing-masing menilai 1 angket. Skor maksimal masing-masing item 5 dan skor minimal yaitu 1 . Skor maksimal keseluruhan angket yaitu 5x36 diperoleh skor maksimal angket sebesar 180, sedangkan skor aktual yang diperoleh dari validator ahli 1 sebesar 156, validator ahli 2 sebesar 158 dan validator ahli 3 sebesar 143, sehingga penliaian akhir pada validator 1 sebesar 86,67\%, validator 2 sebesar 87,87\% dan validator 3 sebesar 79,44\% sehingga diperoleh rata-rata skor akhir sebesar $84,63 \%$ yang berasal dari penjumlahan ketiga skor validator dibagi dengan 3 (jumlah validator) dengan kategori sangat baik.

Tabel 3. Rincian Perolehan Skor Ahli Praktisi Pembelajaran

\begin{tabular}{|c|c|c|c|c|c|c|c|}
\hline \multirow{2}{*}{ Validator } & \multicolumn{4}{|c|}{ Aspek } & \multirow{2}{*}{ Total } & \multirow{2}{*}{ Total Skor Akhir } & \multirow{2}{*}{ Kategori } \\
\hline & 1 & 2 & 3 & 4 & & & \\
\hline Valid & 12 & 30 & 36 & 78 & 156 & $7 \%$ & Sangat Baik \\
\hline Validator ahli 2 & 13 & 30 & 37 & 78 & 158 & $87,78 \%$ & Sangat Baik \\
\hline Validator ahli 3 & 9 & 26 & 33 & 75 & 143 & $79,44 \%$ & Baik \\
\hline
\end{tabular}

\section{c. Validasi Angket Peserta Didik}

Angket ini berisi 31 pernyataan yang harus dinilai oleh ahli dari aspek kemudahan instalasi, komunikasi visual, media pembelajaran dan manajemen pemodelan sistem. Masing-masing item memiliki skor maksimal 5 dan skor minimal 1. Skor maksimal keseluruhan angket yaitu $5 \times 31$ diperoleh skor maksimal angket sebesar 155 . Perolehan skor aktual sebesar 116, sehingga penilaian akhir diperoleh skor 74,84\% dan berada pada kategori Baik.

Tabel 4. Rincian Perolehan Skor Angket Peserta Didik

\begin{tabular}{|c|c|c|c|c|c|c|}
\hline \multicolumn{4}{|c|}{ Aspek } & \multirow{2}{*}{ Total } & \multirow{2}{*}{ Total Skor Akhir } & \multirow{2}{*}{ Kategori } \\
\hline 1 & 2 & 3 & 4 & & & \\
\hline 15 & 25 & 22 & 54 & 116 & $74,84 \%$ & Baik \\
\hline
\end{tabular}

\section{Tahap Implementasi}

Pada tahap implementasi dilakukan pengujian aplikasi pada device, uji coba lapangan dan melakukan penilaian dari peserta didik. Sebelum media pembelajaran divalidasi oleh ahli serta diujicobakan kepada peserta didik, media pembelajaran terlebih dahulu diuji coba secara internal. Setelah coding selesai maka kode program akan di-build dan di-run dengan menggunakan software android studio dilakukan pada device yang sesungguhnya. Device yang diikut sertakan pada tahap pengujian tersebut adalah Samsung Galaxy S8+ dan Asus Zenfone 4 MAX. 
Pengujian selanjutnya dilakukan langsung pada ponsel. Ponsel Samsung Galaxy S8+ dan Asus Zenfone 4 MAX. Asus Zenfone 4 MAX merupakan ponsel mid end Samsung Galaxy S8+ merupakan ponsel high end dengan hasil ujicoba internal aplikasi peserta didik dan internal aplikasi pendidik valid sesuai dengan skenario pengujian.

Uji coba selanjutnya dilakukan kepada 30 peserta didik dikelas XI TKJ SMKN SUKARESIK yaitu dengan menggunakan teknik sampling jenuh yaitu semua anggota populasi digunakan sebagai sampel dengan menggunakan beberapa merek dan tipe ponsel serta operating system yang digunakan. Hasil perolehan skor akhir dari Peserta Didik yaitu $77,72 \%$ yang diperoleh dari skor rata-rata yang dibandingkan dengan skor maksimal jawaban peserta didik yaitu 155 dengan minimal skor yang diperoleh adalah 59. Berdasarkan pada nilai akhir tersebut yaitu 77,72\% masuk dalam kategori Baik.

Tabel 5. Rincian Perolehan Skor Angket Peserta Didik

\begin{tabular}{|c|c|c|c|c|c|c|}
\hline \multicolumn{4}{|c|}{ Aspek } & \multirow{2}{*}{ Total } & Total Skor Akhir & Kategori \\
\cline { 1 - 3 } 1 & 2 & 3 & 4 & & & \\
\hline 346 & 817 & 917 & 1534 & 3614 & $77,72 \%$ & Baik \\
\hline
\end{tabular}

Perolehan jawaban peserta didik disajikan kedalam frekuensi jawaban menggunakan distribusi frekuensi, dimana hasil perhitungan dapat dilihat pada tabel dibawah ini:

Tabel 6. Distribusi Frekuensi Jawaban

\begin{tabular}{|c|c|c|}
\hline Kelas Interval & Frekuensi Jawaban & $\%$ \\
\hline $59-74$ & 1 & $3,3 \%$ \\
\hline $75-90$ & 1 & $3,3 \%$ \\
\hline $91-106$ & 4 & $13,3 \%$ \\
\hline $107-122$ & 8 & $26,7 \%$ \\
\hline $123-138$ & 12 & $40,0 \%$ \\
\hline $139-155$ & 4 & $13,3 \%$ \\
\hline Total & 30 & $100 \%$ \\
\hline
\end{tabular}

\section{Tahap Evaluasi}

Validator ahli rekayasa perangkat lunak dan komunikasi visual merekomendasikan bahwa program dari segi desain diperbaharui sehingga lebih menarik dan fasilitas-fasilitas ditambahkan. Validator ahli praktisi pembelajaran ke 1 merekomendasikan agar list jadwal pelajaran ditambahkan dengan kelasnya. Sementara pada validator ahli praktisi pembelajaran ke 2 dan ke 3 merekomendasikan penggunaan berita, pengumuman dan juga slider image dalam 1 tabel.

Hasil dari penelitian ini membuktikan bahwa aplikasi mobile learning dapat dirancang menggunakan UML (Unified Modeling Language), dimulai dari perancangan use case, class diagram, activity diagram, sqeunce diagram, entity relationship diagram (ERD), logical record structure (LRS) [9]. Metode pengembangan yang digunakan yaitu ADDIE, diawali dengan tahap Analisis (Analysis) yang membahas tentang analisis kebutuhan untuk menentukan media pembelajaran yang tepat, kemudian pada tahap Desain (Design) membahas tentang perancangan keseluruhan dari media pembelajaran yang dibuat, kemudian tahap Pengembangan (Development), Implementasi (Implementation) dan tahap Evaluasi (Evaluation). Akan tetapi pada perancangan ini hanya mencapai tahap Desain (Design) dan dirancang menggunakan UML (Unified Modeling Language).

Berdasarkan pada penelitian sebelumnya yang dilakukan oleh Setyantoko Maranthika [5] pada bagian perancangan hanya menggunakan 2 tahap dalam metode pengembangan ADDIE yaitu tahap analisis dan desain. Tahap analisis pada penelitian sebelumnya membahas tentang analisis kebutuhan pengguna, kebutuhan hardware pengguna dan kebutuhan software yang memiliki kesamaan pembahasan dengan penelitian ini, tetapi analisis kebutuhan pada penelitian ini lebih dijelaskan secara terperinci yaitu mulai dari pengumpulan informasi mengenai masalah-masalah yang muncul dalam pelaksanaan pembelajaran, pengumpulan informasi mengenai sumber daya pendukung pembelajaran yang tersedia, selanjutnya menganalisis kebutuhan dari segi fungsional dan segi non fungsional untuk menuntukan media yang dapat dikembangkan.

Tahap desain pada penelitian sebelumnya membahas desain pembuatan storyboard, perencanaan materi, pengkajian mata pelajaran sesuai dengan kurikulum dan pengumpulan desain backround, font, gambar, serta tombol, dimana terdapat beberapa perbedaan yaitu pada penelitian ini menggunakan perancangan UML (Unified Modeling Language) sebagai tahap awal berupa UML (Unified Modeling Language), dimulai dari perancangan use case, class diagram, activity diagram, sqeunce diagram, entity relationship diagram (ERD), logical record structure (LRS). Perbedaan selanjutnya terletak pada perancangan materi dan pengkajian mata pelajaran dimana pada penelitian ini tidak membahas dalam aspek materi dan mata pelajaran. 
Mobile learning berhasil dibangun menggunakan software Android Studio 4.0 dengan menggunakan Bahasa pemrograman Java untuk android studio dan PHP sebagai penghubung antara android dengan MySQL. Pada tahap ini melanjutkan dari tahap perancangan yaitu analisis dan desain, selanjutnya akan dibahas mengenai tahap Pengembangan (Development), Implementasi (Implementation) dan tahap Evaluasi (Evaluation), dimana pada penelitian sebelumnya yang dilakukan oleh Setyantoko Maranthika (2016: 78-89) hanya sampai pada tahap implementasi dan serta tidak mengikut sertakan tahap evaluasi [5].

Tahap Pengembangan dilakukan untuk membuat produk mobile learning berbasis android, melakukan validasi ahli dan revisi kebutuhan mobile learning. Validasi ahli pada penelitian ini ditujukan kepada ahli Rekayasa perangkat lunak dan komunikasi visual, ahli praktisi pembelajaran. Dimana terdapat perbedaan pada validator, penelitian sebelumnya ditujukan kepada ahli materi dan ahli media, sedangkan pada penelitian ini tidak mengikut sertakan materi pelajaran didalamnya.

\section{Penilaian Aspek rekayasa Perangkat Lunak dan Komunikasi Visual}

Penilaian tertiggi dimiliki oleh aspek rekayasa perangkat lunak yaitu sebesar $82 \%$ yang diperoleh dari hasil bagi nilai aktual pada aspek pertama dengan nilai maksimal pada aspek pertama dan berada pada kategori Sangat Baik, selanjutnya pada peringkat kedua ditempati oleh aspek komunikasi visual yaitu sebesar $80 \%$ berada pada kategori Baik dan nilai terendah dimiliki oleh aspek analisis PIECES yaitu sebesar $72,31 \%$ berada pada kategori Baik. Peroleh skor yang paling rendah terletak pada aspek analisis PIECES yaitu sebesar 72,31\% hal ini terjadi karena aspek berkaitan dengan kualitas sistem. Pada dasarnya produk ini baru saja dikembangkan sehingga membutuhkan pengembangan lebih lanjut untuk mendapatkan kualitas sistem yang lebih baik.

Penelitian sebelumnya milik Maranthika [5] menghasilkan nilai sebesar 4,7 dengan kategori sangat layak pada hasil penilaian validasi ahli media. Hasil tersebut memiliki interpretasi nilai yang berbeda karena terdapat perbedaan cara perhitungan dalam teknik analisis data. Terdapat pula perbedaan dalam aspek yang diukur dimana pada penelitian sebelumnya hanya mengukur aspek rekayasa perangkatlunak dan aspek komunikasi visual sedangkan pada penelitian ini menambahkan aspek analisis PIECES yang berfungsi untuk mengukur kualitas sistem yang terdapat dalam aplikasi. Beberapa perbedaan tersebut menyebabkan perbedaan perolehan nilai akhir dari validasi ahli Rekayasa Perangkat Lunak dan Komunikasi Visual sebesar 77,24\% dalam kategori baik, sedangkan pada penelitian terdahulu menghasilkan nilai akhir sebesar 4,7 yang berada pada kategori sangat baik, yang berarti produk yang telah divalidasi dari segi Rekayasa Perangkat Lunak dan Komunikasi Visual, keduanya layak untuk digunakan.

\section{Penilaian Aspek Media Pembelajaran}

Nilai tertinggi dimiliki oleh aspek media pembelajaran yaitu sebesar $88,33 \%$ pada kategori sangat baik dan nilai terendahnya dimiliki oleh aspek kemudahan instalasi yaitu sebesar 75,56\% pada kategori baik. Dapat dianalisis bahwa aspek kemudahan instalasi memiliki faktor yang mengakibatkan nilai yang dihasilkan rendah yaitu sebagian device dari setiap validator tidak bisa langsung diinstall dikarenakan produk ini belum terupload di google play store sehingga proses installasi terhambat dan perlu beberapa konfigurasi dari setiap device.

Tahap Implementasi dilakukan dengan uji coba kelayakan media pembelajaran secara internal dan eksternal. Uji coba internal dilakukan di 2 device yaitu Samsung Galaxy S8+ dan Asus Zenfone 4 MAX. dari 2 device tersebut menghasilkan kelayakan sesuai dengan kebutuhan. Uji coba eksternal dilakukan secara jarak jauh yaitu dengan membuat group chat yang berisi 30 peserta didik kelas XI TKJ SMKN SUKARESIK. Sebelum media digunakan peserta didik diminta untuk mengunduh aplikasi di google drive dan menginstall aplikasi tersebut di device, setelah itu peserta didik diminta untuk memberikan respon atau pendapatnya untuk mengisi angket yang disediakan oleh peneliti.

Nilai tertinggi dimiliki oleh aspek manajemen pemodelan sistem yaitu sebesar 78,67\% pada kategori baik dan nilai terendahnya dimiliki oleh aspek media pembelajaran yaitu dengan perolehan nilai 76,42\% pada kategori baik. Dapat dianalisis bahwa aspek media pembelajaran memiliki faktor yang mengakibatkan nilai yang dihasilkan rendah yaitu disebabkan oleh jangka waktu pemanfaatan media pembelajaran ini yang dilakukan hanya sebatas untuk uji coba, sedangkan untuk mengetahui aspek media pembelajaran secara keseluruhan harus digunakan secara berkelanjutan, sehingga dapat terlihat secara langsung penilaian dari konteks media pembelajaran tersebut.

Penelitian terdahulu milik Maranthika menghasilkan nilai 6,24 dengan kategori Sangat Layak berdasarkan penilaian yang diberikan peserta didik. Sedangkan penelitian ini berdasarkan penilaian kelayakan dari peserta didik diperoleh nilai sebesar 77,72\% yang berada dalam kategori Baik. Berdasarkan hasil tersebut terdapat perbedaan penilaian akhir yang disebabkan oleh perbedaan aspek yang dinilai berserta indikator dan kondisi pengguna. Selanjutnya interpretasi nilai yang dihasilkan nilai berbeda, hal ini dikarenakan terdapat perbedaan teknik analisis data. 


\section{KESIMPULAN}

Hasil penelitian dapat disimpulkan bahwa mobile learning dapat dirancang dengan menggunakan UML (Unified Modeling Language), dimulai dari perancangan use case, class diagram, activity diagram, sqeunce diagram, entity relationship diagram (ERD), logical record structure (LRS). Mobile learning berhasil dibangun menggunakan software Android Studio 4.0 dengan menggunakan Bahasa pemrograman Java untuk android studio dan PHP sebagai penghubung antara android dengan MySQL. Pembuatan mobile learning berhasil dilakukan secara sistematis dengan menggunakan metode ADDIE yang diawali dengan tahap Analisis (Analysis), tahap Desain (Design), tahap Pengembangan (Development), tahap Implementasi (Implementation) dan tahap Evaluasi (Evaluation). Kelayakan dinilai dari segi rekayasa perangkat lunak dan komunikasi visual yang dihasilkan nilai sebesar 77,24\% dengan kategori Baik. Penilaian oleh praktisi pembelajaran ke 1 menghasilkan nilai sebesar $86,67 \%$ yang berada dalam kategori yang Sangat Baik, penilaian oleh praktisi pembelajaran ke 2 diperoleh nilai sebesar 87,78 dalam kategori Sangat Baik, kemudian pada penilaian oleh praktisi pembelajaran ke 3 diperoleh nilai sebesar 79,44\% yang berada dalam kategori Baik, sehingga nilai rata-rata dari ketiga penilaian oleh validator ahli praktisi pembelajaran yaitu sebesar $84,63 \%$ dengan kategori Sangat Baik. Sedangkan berdasarkan penilaian kelayakan dari peserta didik diperoleh nilai sebesar 77,72\% yang berada dalam kategori Baik.

\section{DAFTAR PUSTAKA}

[1] Arif, Muhammad Budi. 2016. Model pembelajaran ICT Literacy M-Learning untuk meningkatkan hasil belajar mata pelajaran Pendidikan Agama Islam di MTs. Brawijaya Mojokerto. Jurnal Ilmiah Pendidikan Agama Islam, Vol. 6 No. 2, 113-122.

[2] Aripin Ipin. 2018. Konsep Dan Aplikasi Mobile Learning Dalam Pembelajaran Biologi. Jurnal Bio Education, Vol. 3 No.1, 01-09.

[3] Hartanto Wiwin. 2016. Penggunaan E-Learning Sebagai Media Pembelajaran. Jurnal Pendidikan Ekonomi, Vol. 11 No. 2, 131-145

[4] Lavarino, Dio., Yustanti, Wiyli. 2016. Rancang Bangun E - Voting Berbasis Website Di Universitas Negeri Surabaya. Jurnal Manajemen Informatika, Vol. 6 No. 1, 72-81.

[5] Maranthika Setyantoko. 2016. Pengembangan media pembelajaran mobile learning Berbasis android dalam pembelajaran Atletik untuk peserta didik smp kelas VII. Skripsi, tidak diterbitkan, Fakultas Ilmu Keolahragaan, Universitas Negeri Yogyakarta.

[6] Pane Aprida, Dasopang, Muhammad Darwis. 2017. Belajar Dan Pembelajaran. Jurnal Kajian Ilmu-ilmu Keislaman, Vol. 3 No. 2, 333-352.

[7] Sarrab, Mohamed, Laila Elgamel, \& Hamza Aldabbas. 2012. Mobile Learning (M-Learning) and Educational Environments. International Journal of Distributed and Parallel System, 3(4): p. 35

[8] Saragih Hasan. (2008). Kompetensi Minimal Seorang Guru Dalam Mengajar. Jurnal Tabularasa Pps Unimed, Vol. 5 No. 1, 23-34.

[9] Suendri. (2018). Implementasi Diagram UML (Unified Modelling Language) Pada Perancangan Sistem Informasi Remunerasi Dosen Dengan Database Oracle (Studi Kasus: UIN Sumatera Utara Medan). Jurnal Ilmu Komputer dan Informatika, Vol. 3 No. 1, 1-9.

[10] Sunhaji. 2014. Konsep Manajemen Kelas dan Implikasinya Dalam Pembelajaran. Jurnal Kependidikan, Vol.2 No.2, $30-46$.

[11] Yudhanto, Yudha; Wijayanto, Ardhi,, Mudah Membuat dan Berbisnis Aplikasi Android dengan. Android Studio, Jakarta: PT Elex Media Komputindo, 2017

[12] Zulfiandri, Z., Hidayatuloh, S. \& Anas, M., 2014. Rancang Bangun Aplikasi Poliklinik Gigi (Studi Kasus: Poliklinik Gigi Kejaksaan Agung RI). In Prosiding Seminar Ilmiah Nasional Komputer dan Sistem Intelijen (KOMMIT 2014). 8. Seminar Ilmiah Nasional Komputer dan Sistem Intelijen. Depok: Universitas Gunadarma, pp. 473-482. 


\section{Biodata Penulis}

Ms Chandra Tri Saputra, memperoleh gelar Sarjana Pendidikan (S.Pd), Program Studi Pendidikan Teknologi Informasi Universitas Muhammadiyah Tasikmalaya (UMTAS), lulus tahun 2020.

Taofik Muhammad, memperoleh gelar Sarjana Pendidikan (S.Pd), Program Studi Pendidikan Ilmu Komputer UPI Bandung, lulus tahun 2011. Tahun 2013 memperoleh gelar Magister Komputer (M.Kom) dari Program Studi Sistem Informasi STMIK LIKMI Bandung. Saat ini sebagai Dosen tetap Program Studi Pendidikan Teknologi Informasi Universitas Muhammadiyah Tasikmalaya (UMTAS).

Muhammad Taufiq, memperoleh gelar Insinyur, Program Studi Teknik Perminyakan UPN "Veteran" Yogyakarta, lulus tahun 1990. Tahun 2013 memperoleh gelar Magister Komputer (M.Kom) dari Program Magister Teknik Informatika STMIK AMIKOM Yogyakarta. Saat ini sebagai Dosen tetap Program Studi Pendidikan Teknologi Informasi Universitas Muhammadiyah Tasikmalaya (UMTAS). 